\title{
Iosif Viehmann - a lifetime dedicated to cave and karst
}

\author{
Bogdan P. Onac ${ }^{1,2^{*}}$ \\ ${ }^{1}$ School of Geosciences, University of South Florida, Tampa, USA \\ “Emil Racoviță” Institute of Speleology, Cluj-Napoca, Romania
}

Iosif (Pepi) Viehmann, a former karst scientist in the "Emil Racoviță" Institute of Speleology (Cluj, Romania), passed away on August 6, 2016 at age 90. Born on September 1, 1925 and raised in Cluj, his childhood, and especially his adolescence, were marked by turbulent historical events on the eve of World War II. Between 1946 and 1950, Pepi attended the Faculty of Natural Sciences at the "Regele Ferdinand I" University (now „Babeş-Bolyai” University) in Cluj. During his first year in college, he had the chance to meet and be inspired by Emil Racoviță, who founded the world's first Speleological Institute in Cluj in 1920. From Racoviță, Pepi inherited the skills to develop scientific and popularization conferences peppered with charming stories and illustrated with slide projections covering many karst- and cave-related topics.

After graduation, Pepi spent five years as a Natural Science teacher at the Pedagogical School in Năsăud. During his tenure, he teamed up with another local teacher (L. Bîrte) and discovered the Tăuşoare Cave (Rodnei Mountains) (Viehmann \& SSerban, 1963; Viehmann et al., 1964b). Subsequently, in 1958, Pepi returned to Cluj to join the research group at the Speleological Institute. He dedicated more than 50 years to the exploration and study of several karst regions in Romania; the karst of the Apuseni and Rodnei mountains were closest to his heart.

The text below is a modified version of a note I wrote in September 2000 when celebrating our colleague and friend Pepi Viehmann on his $75^{\text {th }}$ birthday. I realize now that this note best characterizes Pepi Viehmann's activity, which identifies with the postwar beginnings of scientific speleology in Romania. His activity, longer than half a century, has been highlighted by many achievements in both exploration and publication. He was a member of teams that made exceptional cave discoveries and explorations during the '50s and '60s. Along with Mihai Şerban, Marcian Bleahu, Emilian Cristea, Dan Coman, Theodor Rusu, Corneliu Pleşa, Gheorghe Racoviță, and Valentin Crăciun, he surveyed caves such as Pojarul Poliței, Vârtop, Cetățile Ponorului, Şesuri, Căput, VaduCrişului, Neagră, Gemănata, Tăuşoare, Jgheabul lui Zalion, Iza, and Urşilor, to name only a few (Viehmann, 1967, 1973; Bleahu \& Viehmann, 1963; Viehmann et al., 1964a, 1979, 1980). However, a brief examination of the references included in four different editions of Peşteri din România (Caves of Romania) reveals Pepi Viehmann's name on numerous cave maps, indicating his significant contribution and assiduous field activity.

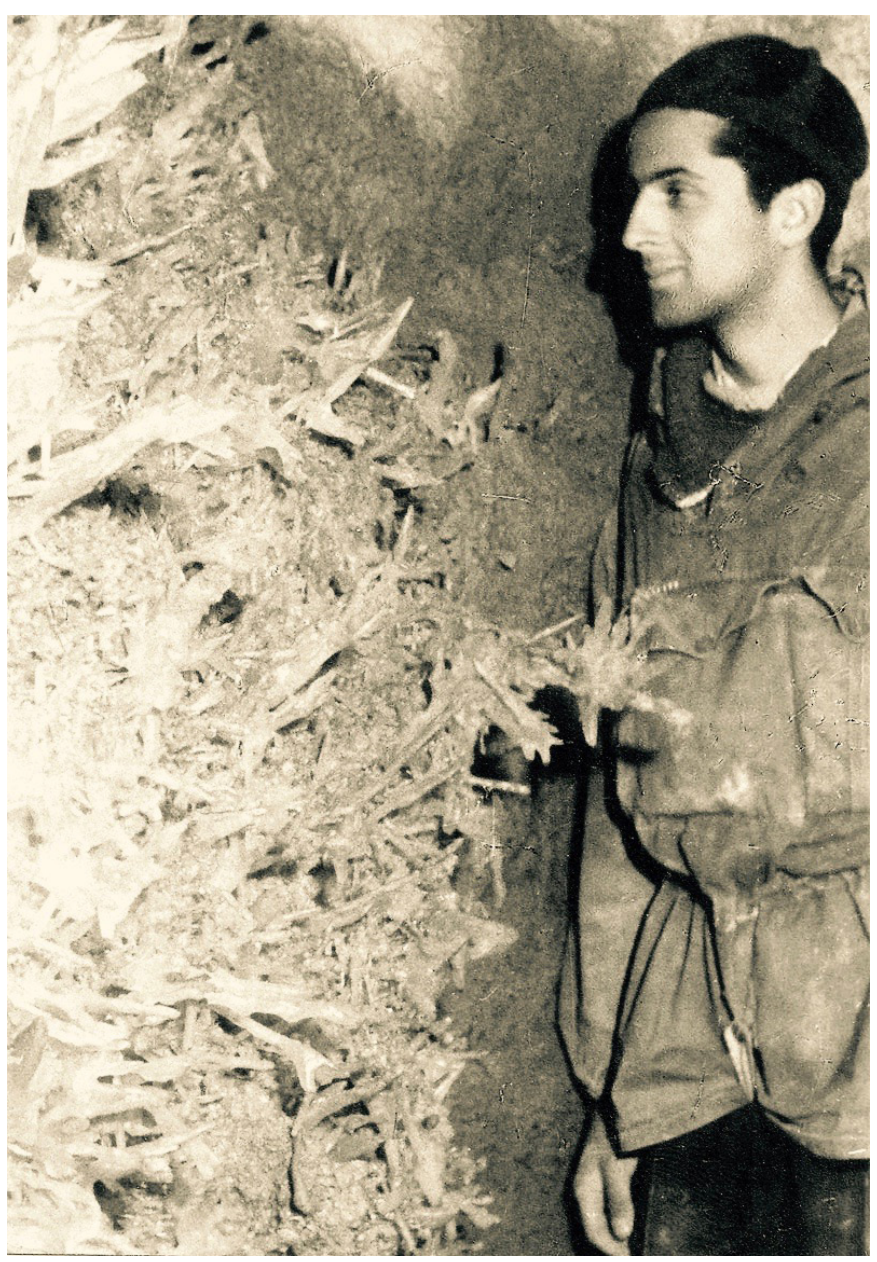

Fig. 1. Image of Pepi from 1949 while exploring and mapping the Pojarul Poliței Cave, Romania (photo: M. Șerban).

From a scientific point of view, Pepi Viehmann published more than a hundred papers in Romanian and foreign journals. Among these are monographs concerning karren and stream whirlpools (Viehmann, 1959a, 1964), as well as a series of studies on the genesis and morphology of cave pearls (Viehmann, $1957,1959 b, 1993)$. He is the main author of the 
Ghețarul de la Scărişoara and Bears Cave photo albums (Viehmann et al., 1968; Viehmann \& Guja, 2014), and the co-author of two other books illustrating and describing the caves of Romania (Şerban et al., 1961; Bleahu et al., 1976). He is also the author of General Speleology, a textbook for students that was published in 2000, and another cave album dedicated to the Vîrtop Cave (Guja \& Viehmann, 2013).

One of Pepi Viehmann's many significant scientific activities was the Ghețarul de la Scărişoara, where each month for over 40 years, he gathered climatic and glaciological data, which were used in several papers (Viehmann et al., 1965; Viehmann, 1969; Viehmann \& Racoviță, 1982; Racoviță \& Viehmann, 1985; Racoviță et al., 1987).

Gifted with a special capacity of observation, understanding of how to value each detail, and mastery in designing original methods to explain various genetic processes, Pepi Viehmann surprised the scientific community with some very ingenious experiments. He used nail polish to mark numerous cave pearls and cave rafts to examine their evolution (Viehmann, 1959a, b, 1962, 1992; Viehmann et al., 1997), ringed eccentric speleothems with a chemical pencil to prove the anti-gravitational crystallogenesis process, and revealed the presence of the permanent drop on top of helictites (Viehmann, 1962). Very early in his professional career, Pepi published a series of papers on genesis and classification of speleothems (Viehmann, 1958, 1975a, 1976), as well as on the mineralogy of various cave minerals and deposits (Diaconu et al., 1977; Viehmann et al., 1981; Onac \& Viehmann, 1987; Onac et al., 2001).

Pepi Viehmann's name is also linked to the sensational discoveries of the prehistoric human footprints in the clay of Ciur-Izbuc Cave (Rusu et al., 1969; Webb et al., 2014) and in the hardened moonmilk of the Vârtop Cave (Casa de Piatră) (Viehmann, 1975b; Viehmann et al., 1982, 1996; Onac et al., 2005). He is also known for his thorough observations on the cave bear traces and their cohabitation with the prehistoric humans (Viehmann, 1987).

An excellent pedagogue and good mate during field campaigns, he led several series of students through the fascinating world of caves with professionalism. He shared his love of speleology with the help of charming slideshows and unforgettable caving camps. He helped anyone seeking advice, and was loved and appreciated by all. To his merit, Pepi not only discovered some outstanding Romanian caves, but he also continuously discovered people, who in turn discover and study new caves.

The boundless love and passion for the magnificent world of karst was the secret of his youth and power of work. All these characteristics made Pepi Viehmann a continuous stimulus for the young generation in the Speleological Institute and beyond. Pepi's death has deprived the karst community, jazz fans, and many others of his enthusiasm and charm, and he will be very much missed by his many friends and colleagues. He is survived by his wife, Alina, and his children, Radu and Cristina.
Selected books, chapter, edited (co-edited) volumes, and papers by Iosif Viehmann:

Bleahu M. \& Viehmann I., 1963. - Virtop Ice Cave. Ocrotirea Naturii, 7: 147-152. (in Romanian).

Bleahu M., Decu V., Negrea Ş., Pleşa C., Povară I. \& Viehmann I., 1976 - Caves of Romania. Ed. Ştiințifică şi Enciclopedică, Bucureşti, 415 p. (in Romanian).

Diaconu G., Medeşan A. \& Viehmann I., 1977 - Une nouvelle paragenäse minéralogique dans la grotte "Peştera Fagului", Département de Bihor (huntite, hydromagnesite, aragonite, calcite). Travaux de 1'Institute de Spéologie "Emile Racovitza", XVI: 203-210.

Guja O. \& Viehmann I., 2013 - Virtop Ice Cave. Societatea Națională de Speologie, Cluj-Napoca, 64 p.

Onac B.P. \& Viehmann I., 1987 - Origines et formes d'apparition du gypse dans Pestera Vintului (Monts Pădurea Craiului). Theoretical and Applied Karstology, 3: 243-245.

Onac B.P., White W.B. \& Viehmann I., 2001 - Leonite $\left[\mathrm{K}_{2} \mathrm{Mg}\left(\mathrm{SO}_{4}\right)_{2} 4 \mathrm{H}_{2} \mathrm{O}\right]$, konyaite $\left[\mathrm{Na}_{2} \mathrm{Mg}\left(\mathrm{SO}_{4}\right)_{2} 5 \mathrm{H}_{2} \mathrm{O}\right]$, and syngenite $\left[\mathrm{K}_{2} \mathrm{Ca}\left(\mathrm{SO}_{4}\right)_{2} \mathrm{H}_{2} \mathrm{O}\right]$ from Tãuşoare Cave (Rodnei Mts., Romania). Mineralogical Magazine, 65 (1): 1-7.

Onac B.P., Viehmann I., Lundberg J., Lauritzen S.-E, Stringer C. \& Popiță V., 2005 - U-Th ages constraining the Neanderthal footprint at Vârtop Cave, Romania. Quaternary Science Reviews, 24: 1151-1157.

Racoviță G. \& Viehmann I., 1985 - Étude de l'evapocondensation souterraine dans une grotte glaciàre. Theoretical and Applied Karstology, 2: 123-130.

Racoviță G., Şerban M. \& Viehmann I., 1987 - Tendances de long terme dans la dynamique des formations de glace de la Grotte de Scărişoara (Monts de Bihor). Theoretical and Applied Karstology, 3: 143-163.

Rusu T, Viehmann I., Racoviță G. \& Crăciun V., 1969 Primele urme de paşi ale omului preistoric din peşterile Romaniei (First footprints of prehistoric humans from Romanian caves). Ocrotirea Naturii, 13: 191-200.

Şerban M., Viehmann I. \& Coman D., 1961 - Caves of Romania. Ed. Meridiane, Bucureşti, 33 p + illustrations.

Viehmann I., 1957 - Perlele de cavernă din Ghețarul de la Scărişoara. Dări de Seamă ale Şedințelor Comitetului Geologic, XLV: 283-295.

Viehmann I., 1958. Le formations stalagmitiques des grottes du complexe karstique de Scărişoara. Mémoires du Colloquium International de Spéléologie de la Fédération Spéléologique de Belgique, 1: 73-80.

Viehmann I., 1959a - Contributions à la connaissance de la génèse des marmites. Speleologia, I.3: 145-175.

Viehmann I., 1959b - Un nouveau processus de génèse des perles de caverne. Ceskoslovensky Kras, 12: 1-9.

Viehmann I., 1962 - Contributions to the understanding of helictites genesis. Dări de Seamă ale Şedințelor Comitetului Geologic, XLIII: 659-670. (in Romanian with French abstract)

Viehmann I., 1963 - Un nou proces de geneza a perlelor de caverna (Un nouveau processus de génèse des perles de caverne). Lucrările Institutului de Speologie "Emil Racoviță", I-II: 295-303.

Viehmann I., 1964 - Note cu privire la geneza lapiezurilor. Dări de Seamă ale Şedințelor Comitetului Geologic, XLIX (1961-1962): 271-288.

Viehmann I., 1967 - Pojarul Poliței Cave. Ocrotirea Naturii, 11 (2): 61-73.

Viehmann I., 1969 - Methoden für experimentelle Forschung im Studium der Eishöhlen. V. Internationaler Kongress für Speläologie, Stuttgart, 2: S29/1-3.

Viehmann I., 1973 - Résultats de l'expédition BelgoRoumaine de la grotte de Tăuşoare (Monts Rodna, 1971). Proceedings of the $6^{\text {th }}$ International Congress of Speleology, Academia, Praha, p. 229-232. 
Viehmann I., 1975a - Quelques considérations sur l'aragonite et les cristallisations excentriques des grottes. Travaux de l'Institute de Spéologie "Emile Racovitza", XIV: 141-147.

Viehmann I., 1975b - 15,000-yearold life traces. Radiotele Şcoală, February, p. 33-34. (in Romanian).

Viehmann I., 1976 - Essai de classification des formes souterraines des grottes. Actes du $6^{\mathrm{e}}$ Congres International de Spéléologie, Oloumouc, III: 289-293.

Viehmann I., 1987 - Traces of the cave bear's life. Travaux de l'Institute de Spéologie "Emile Racovitza", XXVI: 73-79.

Viehmann I., 1992 - Experimental methods in studying the cave rafts. Theoretical and Applied Karstology, 5: 213-215.

Viehmann I., 1993 - Note sur des perles de caverne particulières. Bulletin de la Société géographique de Liège, 29: 105-107.

Viehmann I., 2000 - General speleology. Ed. Presa Universitară Clujeană, Cluj-Napoca, 200 p.

Viehmann I. \& Guja O., 2014 - Bears Cave from Chişcău. Societatea Națională de Speologie, Cluj-Napoca, 64 p.

Viehmann I. \& Racoviță G., 1982 - Le stalagmiti di ghiaccio termoindicatrici. Speleologia, 7: 26-27.

Viehmann I. \& Şerban M., 1963 - Notă preliminară asupra Peşterii de la Izvorul Tăuşoarelor (Munții Rodnei) (Preliminary note on the Izvorul Tăuşoarelor Cave, Munții Rodnei). Lucrările Institutului de Speologie "Emil Racoviță", I-II: 179-207.

Viehmann I., Bucur I. \& Racovițan I., 1982 - Human prehistoric footprints in Romanian caves. Carst, 2: 37-43 (in Romanian).

Viehmann I., Ghergari L. \& Onac B.P., 1997 Crystallographical observations on calcite rafts from three Romanian caves. Proceedings of the $12^{\text {th }}$ International Congress of Speleology, La Chaux-deFonds, 1: 227-230.

Viehmann I., Lauritzen S.-E. \& Onac B.P., 1996 - The Vârtop Cave man and his radiometric age. Karst Waters Institute Special Publication, 2: 170-171.

Viehmann I., Racoviță G. \& Şerban M., 1965 - Observații asupra microclimei Ghețarului de la Scărişoara (Microclimatic observations on the Scărişoara Ice Cave). Lucrările Institutului de Speologie "Emil Racoviță", IV: $105-115$

Viehmann I., Racoviță G. \& Şerban M., 1968 - Scărișoara Glacier Cave. Ed. Meridiane, Bucureşti, $80 \mathrm{p}$.
Viehmann I., Pleşa C. \& Rusu T., 1964a - Peştera de la Vadu-Crişului. Travaux de l'Institute de Spéologie "Emile Racovitza", III: 49-81.

Viehmann I., Rusu T. \& Şerban M., 1964b - Complexul carstic Tăuşoarelor-Zalion (Munții Rodnei) (TăuşoareZalion karst complex, Munții Rodnei). Lucrările Institutului de Speologie "Emil Racoviță", III: 21-48.

Viehmann I., Silvestru E. \& Fabian C., 1979 - La "grotte d'Iza" (Monts de Rodna, Roumanie). Travaux de l'Institute de Spéologie "Emile Racovitza", XVIII: 201-207.

Viehmann I., Demeter I., Lungu V. \& Sarkady P., 1981 Note préliminaire sur l'argile blanche de la grotte d'Iza (Monts de Rodna, Roumanie). Travaux de l'Institute de Spéologie "Emile Racovitza", XX: 213-215.

Viehmann I., Cristea E., Şerban M., Cuc O. \& Ghitea S., 1980 - La morphologie du complexe karstique "Cetățile Ponorului" (Les Monts Apuseni, Roumanie). Travaux de l'Institute de Spéologie "Emile Racovitza", XIX: 261-274.

Webb D., Robu M., Moldovan O., Constantin S., Tomuş B. \& Neag I., 2014 - Ancient human footprints in CiurIzbuc Cave, Romania. American Journal of Physical Anthropology, 155: 128-135.

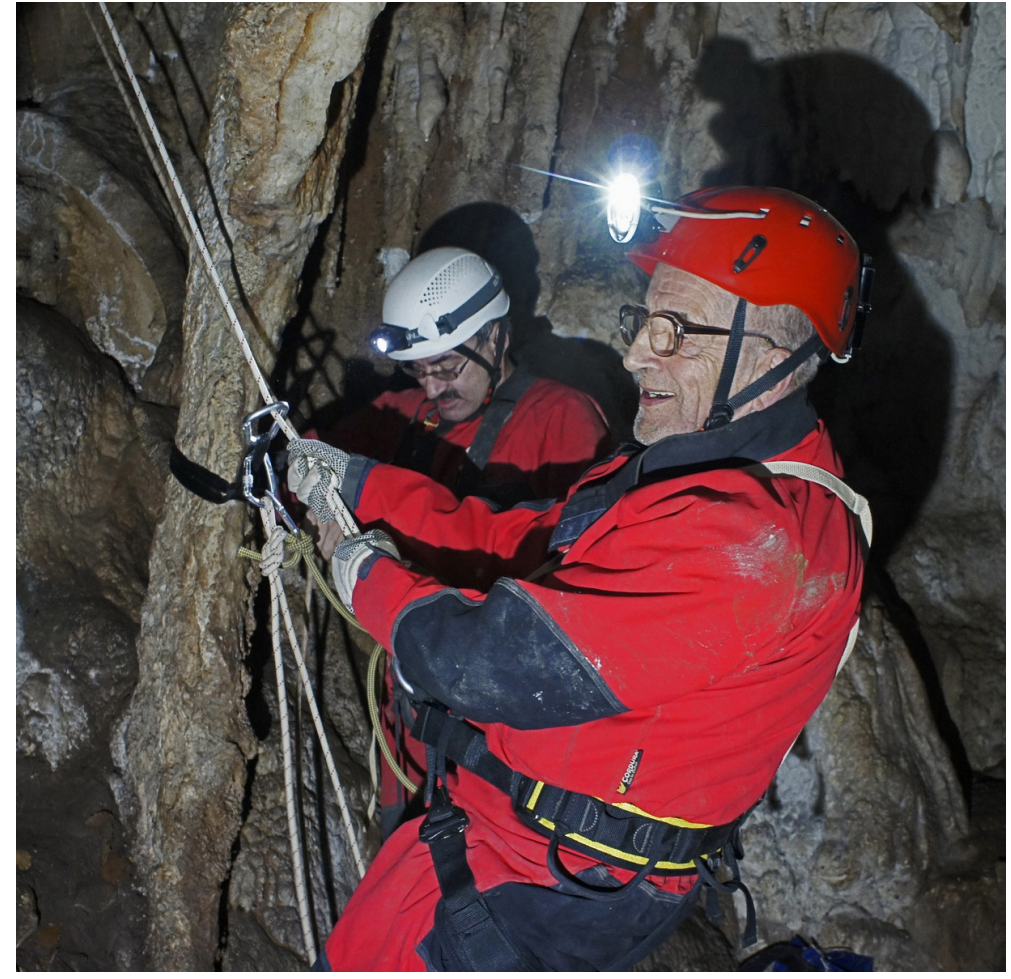

Fig. 2. In October 2012, at age 87, Pepi returned to Pojarul Poliței Cave (photo: Ch. Ciubotărescu). 